\title{
A multivariate analysis of taxonomic limits in Diplolaemus Bell 1843
}

\section{Un análisis multivariado de los límites taxonómicos en Diplolaemus Bell 1834}

\author{
Pedro F. Victoriano ${ }^{1,2, *}$, Tania M. Coronado ${ }^{1}$ \& Juan Carlos Ortiz ${ }^{1,2}$ \\ ${ }^{1}$ Departamento de Zoología. Facultad de Ciencias Naturales y Oceanográficas, Universidad de Concepción, Casilla 160-C, \\ Concepción, Chile. \\ ${ }^{2}$ Centro de Investigaciones en Ecosistemas Patagónicos. Coihaique, Chile. \\ *E-mail: pvictori@udec.cl
}

\begin{abstract}
The genus Diplolaemus Bell, 1843 is a common squamate component of the Patagonian region of South America. Considerable taxonomic confusion exists within this genus, particularly about the status of Chilean-Andean populations and the actual distribution of D. leopardinus (Werner, 1898). In an attempt to clarify the taxonomic status and distribution of Diplolaemus species, we performed a principal component analysis (PCA) and discriminant function analysis (DFA) using both standard morphometric and meristic data. Multivariate summaries of morphometric data show that most species are poorly discriminated, with the exception of $D$. darwinii. In contrast, a PCA analyses performed on the meristic data clearly distinguish three discrete groups: 1 . D. darwinii, 2. D. sexcinctus including the Chilean populations, and 3. populations from Mendoza, Argentina, including the holotype of $D$. leopardinus and of $D$. bibronii. A DFA consistently assigned with a high percentage of successful classification (95\%) individuals of the species $D$. darwinii, D. sexcinctus, and D. bibronii. The group with lowest successful rate in the cross validation procedure $(78 \%)$ was $D$. leopardinus (including populations from Mendoza), with misidentifications assigned only to D. bibronii. The group formed by Mendoza populations and the holotype of $D$. leopardinus is visibly distinct from remaining $D$. bibronii in colour patterns. The holotype of $D$. leopardinus is clearly differentiated from the Chilean-Andean populations. Our results support the assignment of populations from Mendoza to D. leopardinus, and suggest that the Chilean-Andean populations currently assigned to this taxon should be referred as $D$. sexcinctus, together with populations from the Argentinean provinces of Río Negro and Neuquén.
\end{abstract}

KEYwords: Species limits, taxonomy, Patagonia, Polychrotidae.

\section{RESUMEN}

El género Diplolaemus Bell, 1843 es un lagarto típico de la región patagónica de Sudamérica. Aún existe considerable confusión taxonómica dentro de este género, especialmente en torno al estatus de las poblaciones andino-chilenas y de la distribución actual de $D$. leopardinus (Werner, 1898). En un intento de aclarar la situación taxonómica y distribución de las especies del género, realizamos análisis de componentes principales (PCA) y de funciones discriminantes (AFD), usando tanto variables morfométricas como merísticas. En síntesis, los datos morfométricos indican que el género es altamente conservado morfológicamente por lo que la mayor parte de las especies son pobremente discriminadas, con la excepción de $D$. darwinii. En contraste, el PCA realizado con datos merísticos claramente distingue tres grupos: 1. D. darwinii, 2. D. sexcinctus incluyendo las poblaciones chilenas de Alto Biobío, y 3. Poblaciones mendocinas incluyendo al holotipo de $D$. leopardinus más $D$. bibronii. El análisis de AFD asignó consistentemente y con un alto porcentaje de éxito en la clasificación (95\%), individuos de las especies $D$. darwinii, D. sexcinctus y D. bibronii. El grupo con la menor tasa de éxito en la validación cruzada (78\%) fue $D$. leopardinus (incluyendo las poblaciones mendocinas), donde todas las asignaciones erradas fueron a $D$. bibronii. El grupo de las poblaciones mendocinas más el holotipo de D. leopardinus son claramente distintos de $D$. bibronii en cuanto al patrón de coloración. El holotipo de D. leopardinus es claramente distinguido de las poblaciones chilenas de Alto Biobío. Estas últimas son poblaciones andinas asignables a $D$. sexcinctus. Nuestros resultados soportan la asignación de las poblaciones mendocinas a la especie D. leopardinus, y sugieren que las especies andinas de Alto Biobío en Chile, previamente tratadas con este nombre específico, debieran ser asignadas a $D$. sexcinctus, junto a las poblaciones de Río Negro y Neuquén de Argentina.

Palabras clave: Límites de especies, taxonomía, Patagonia, Polychrotidae. 


\section{INTRODUCTION}

Lizards of the genus Diplolaemus (Leiosauridae) distribute across the Patagonian Province in Chile and Argentina, and extend north and northwest along the edge of the Andes and into valleys characterized by the typical physiognomy of this biogeographical formation (Cei 1971, Cei 1979). The genus was described by Bell (1843) in the Charles Darwin volume which report the material collected during the expedition of the H.M.S. Beagle. At that time, two species, D. darwinii and D. bibronii, were described from Puerto Deseado, Santa Cruz Province, Argentina (Fig. 1). These species are sympatric across a wide geographic range that includes southern Argentina and adjacent Chile (Fig. 2, Cei 1986, Avila et al. 2001, Ibargüengoytia \& Schulte 2001).

In his taxonomic treatment, Boulenger (1885), without justification, synonymized $D$. bibronii with $D$. darwinii. Later workers resurrected D. bibronii based on clear differences in scalation and color pattern (Anderson 1898, Stejneger 1909, Donoso-Barros \& Codoceo 1962, Peters \& Donoso-Barros 1970). The diagnostic features identified by these authors are clearly valid for Diplolaemus populations in southern Argentina and Chile. However, in northern areas extensive phenotypic variation prevents the unambiguous assignment of some populations either to $D$. darwinii or to D. bibronii populations (Cei 1986, Cei et al. 2003). Stejneger (1909) reported on this extensive phenotypic variation in some populations, at the time that discussed the possible occurrence of a new species in the northern range, based on an individual whose characteristics were intermediate between $D$. darwinii and $D$. bibronii.

Werner (1898) described D. leopardinus (Fig. 3 and 4), based on individuals from the collection Plate, which was made from 1893 up 1895, and designated Santiago (Chile) as the type locality. No additional specimens have ever been found in the vicinity of the type locality. Donoso-Barros $(1965 ; 1974)$ collected several individuals of Diplolaemus from Laguna del Laja National Park in the Central Chilean Andes, which he identified as D. leopardinus. He also indicated that its distribution did not reach the type locality (Santiago of Chile) indicated by Werner (1898). Cei (1986) recognized two undescribed Argentinean forms which he referred to as the "forma alto patagónica" (high Patagonian form), and "forma mendocina" (Mendoza form). Cei`s high Patagonian form occurs in the Andes and sub-Andean volcanic regions of Patagonia, from approximately $37^{\circ} \mathrm{S}$ up $41^{\circ} \mathrm{S}$, while the Mendoza form occurs in Mendoza Province, Argentina, but neither was formally described.

Due to this taxonomic confusion, we have reconsidered the status of D. leopardinus and the two forms of Cei (1986). Recently, Cei et al. (2003) described the new species $D$. sexcinctus on the basis of the "alto patagónica" populations; its holotype is from Río Negro, Argentina, and these authors included within this species the populations from Mendoza. These authors maintain the original interpretation that D. leopardinus is distributed in Chile, in Laguna del Laja (referring to Donoso Barros 1966), and its unresolved relationship with $D$. sexcinctus require further research. The objective of this work is to summarize the meristic and morphometric variation among all recognized species of Diplolaemus, with an emphasis in the Andean-Chilean populations and the distribution of $D$. leopardinus.

\section{MATERIALS AND METHODS}

We have analyzed 125 individuals of all the recognized species of Diplolaemus. Details about the number of individuals for each species are shown in Table 1. Details about localities from where lizards were collected are included in Appendix 1. Some of the lizards used in this study were obtained from the northwest slope of Antuco Volcano in Chile (37 $\left.21^{\circ} \mathrm{S}-71^{\circ} 19^{\circ} \mathrm{O}\right)$, during fieldtrips to the Laguna del Laja National Park (Región del Biobío, Chile), in the late spring and summer of 2000. Procedures of transport, caging, care and euthanasia were according to Greene (1995). Voucher specimens were deposited in the Museo de Zoología de la Universidad de Concepción (MZUC). Individuals described by Cei et al. (2003; D. sexcinctus) were borrowed from the Sociedad Naturalista Andino Patagónica of San Carlos de Bariloche, Argentina (MIC), or the Instituto de Biología Animal, Universidad Nacional de Cuyo, Argentina (IBA). The type series of D. darwinii Bell, 1843 and D. bibronii Bell, 1843, were borrowed from the British Museum Natural History, England $(\mathrm{BMNH})$, and other samples were obtained from Museo Regional de Concepción, Chile (MCR), the Museo Nacional de Historia Natural de Montevideo, Uruguay (MNHM), and the Museo Nacional de Historia Natural de Santiago, Chile (MNHN). The holotype of D. leopardinus (Werner, 1898) was borrowed from the Zoologischen Museum Berlin, Germany (ZMB). Locality and other data of the specimens examined are presented in Appendix 1.

Following the methods of Lamborot \& Díaz (1987), morphometric measures were obtained to the nearest 0.1 $\mathrm{mm}$ using a digital caliper. The nomenclature of the meristic (scalation) characters was based principally on DonosoBarros (1966) and Cei (1986). To indicate the shape, number, and relative location of the holotype's cephalic scales, outlines were drawn using a stereozoom microscope. The abbreviations used for the meristic and morphometric characters were: SPL (supralabial scales, counted on one side), INF (infralabial scales, counted on one side ), SNR (scales between nasal and rostral scale), SSoSp (scales 
between suboculars and supralabials), SNG (scales between snout and gular fold), PSF (postfacial scales, counted on both sides), INPM (scales between infralabial and postmental), SEE (scales between eye and ear-opening), PMS (postmental scales, counted on one side), SAB (scales around midbody), SMDL (scales along middorsal line), SMDH (scales along the middorsal line on the head, counted from the rostral one to the neck), SVL (snout-vent length), TL (tail length), MAX (maximum head width), HL (head length, measured from snout to the ear opening), DEO (distance from ear opening to eye), DEN (eye-nostril distance), DPOEF (distance from posterior border of eye to facial), DIS (distance from interparietal to snout), and SGF (distance from snout to gular fold).

The data were analyzed using STATISTICA V. 5.1., after a $\log$ transformation directed to eliminate the heterogeneity of variances. We have included exclusively adult individuals in the multivariate analysis in order to exclude some ontogenetic effect on the results. We applied a diagnostic test for normality and heterogeneity of variance (with log transformed data), and then used nine morphometric and 12 meristic characters in an exploratory analysis (Principal component analysis, PCA), to determine what combinations of characters (if any) delimited groups concordant with the previously described species, and to determine what differences discriminated among the species included in this work. Subsequently, an analysis of mean differences was performed between species for the meristic characters with a MANOVA. After these analyses, a post-hoc Tukey's test was conducted to compare species, and for each one of the scalation characters. To test the reliability of the meristic data to correctly assign individuals to each of the respective species, a discriminant function analysis was conducted, and when the functions were determined, a cross validation procedure was applied to test the reliability of each function.

\section{RESULTS}

VARIATION AND COMPARATIVE ANALYSIS. Table 1 presents the sample size by species including both adults and subadults individuals, the mean, standard deviation, and range of the morphometric and meristic characters of the four studied species of Diplolaemus. In general, the greatest differences between species were detected in the meristic characters, particularly those of the head. Due to the extensive overlap of the morphometric characters, these were not useful for discriminating between species. However, clear differences exist for a large number of meristic characters that unambiguously discriminate $D$. darwinii from the other species. D. darwinii does not overlap with any other species, including $D$. sexcinctus, for the character SPL, while PMS differentiate it from $D$. bibronii and $D$. leopardinus. In addition, $D$. darwinii does not overlap with $D$. leopardinus in INF, SNR, SNG, and INPM. Even though D. sexcinctus is not easily differentiated because it usually overlap in meristic characters with all other species, it does show important differences in two characters (INPM and PMS) relative to $D$. leopardinus and $D$. bibronii. For posterior analysis we used only adult individuals; $D$. sexcinctus $=42$, D. bibronii $=40$, D. leopardinus $=9$ and $D$. darwinii $=7$.

TABLE 1. Sample size for each species, mean \pm standard deviation of the morphometric (measurements in millimeters) and meristic (scalation) characters for species of Diplolaemus; ranges in parentheses. See text for variable abbreviations.

TABLA 1. Número de individuos por especie, promedio y desviación estándar de los caracteres morfométricos (medidos en milímetros) y merísticos para especies del género Diplolaemus; rangos en paréntesis. Ver el texto para las abreviaciones de las variables.

\begin{tabular}{lcccc}
\hline Character & D. sexcinctus & D. bibronii & D. leopardinus & D. darwinii \\
$\mathrm{n}=56$ & $\mathrm{n}=47$ & $\mathrm{n}=12$ & $\mathrm{n}=10$ \\
\hline SPL & $12,11 \pm 0,56$ & $11,79 \pm 0,72$ & $12,33 \pm 0,65$ & $9,90 \pm 0,30$ \\
& $(11-14)$ & $(11-13)$ & $(11-13)$ & $(9-10)$ \\
INF & $11,75 \pm 0,84$ & $11,68 \pm 0,78$ & $11,67 \pm 0,65$ & $9,40 \pm 0,49$ \\
& $(10-14)$ & $(10-13)$ & $(11-13)$ & $(9-10)$ \\
SNR & $2,82 \pm 0,58$ & $2,98 \pm 0,44$ & $3,08 \pm 0,39$ & $1,30 \pm 0,46$ \\
& $(2-4)$ & $(2-4)$ & $(3-4)$ & $(1-2)$ \\
SSoSp & $3,07 \pm 0,63$ & $3,83 \pm 0,48$ & $3,75 \pm 0,50)$ & $2,30 \pm 0,46$ \\
& $(2-4)$ & $(3-5)$ & $(3-4)$ & $(2-3)$ \\
SNG & $63,25 \pm 4,69$ & $66,06 \pm 4,81$ & $68,75 \pm 3,72$ & $53,10 \pm 2,51$ \\
& $(54-73)$ & $(51-75)$ & $(64-75)$ & $(50-57)$ \\
\hline
\end{tabular}


Gayana 74(1), 2010

Table 1, continued

\begin{tabular}{|c|c|c|c|c|}
\hline Character & $\begin{array}{c}\text { D. sexcinctus } \\
\mathrm{n}=56\end{array}$ & $\begin{array}{c}\text { D. bibronii } \\
\mathrm{n}=47\end{array}$ & $\begin{array}{l}\text { D. leopardinus } \\
\mathrm{n}=12 \\
\end{array}$ & $\begin{array}{c}\text { D. darwinii } \\
\mathrm{n}=10\end{array}$ \\
\hline PSF & $\begin{array}{l}3,52 \pm 0,57 \\
\quad(2-4)\end{array}$ & $\begin{array}{l}3,87 \pm 0,65 \\
\quad(3-6)\end{array}$ & $\begin{array}{l}3,75 \pm 0,43 \\
\quad(3-4)\end{array}$ & $\begin{array}{l}3,90 \pm 0,54 \\
\quad(3-5)\end{array}$ \\
\hline INPM & $\begin{array}{l}9,48 \pm 1,64 \\
\quad(7-12)\end{array}$ & $\begin{array}{c}12,64 \pm 1,67 \\
(9-17)\end{array}$ & $\begin{array}{c}12,00 \pm 0,92 \\
(11-14)\end{array}$ & $\begin{array}{c}8,00 \pm 0,63 \\
(7-9)\end{array}$ \\
\hline SEE & $\begin{array}{c}22,27 \pm 2,35 \\
(18-28)\end{array}$ & $\begin{array}{c}25,98 \pm 2,82 \\
(21-32)\end{array}$ & $\begin{array}{c}23,75 \pm 1,95 \\
(21-27)\end{array}$ & $\begin{array}{c}18,90 \pm 1,45 \\
(17-22)\end{array}$ \\
\hline PMS & $\begin{array}{l}2,04 \pm 0,19 \\
\quad(2-3)\end{array}$ & $\begin{array}{c}3,91 \pm 0,28 \\
\quad(3-4)\end{array}$ & $\begin{array}{l}3,83 \pm 0,61 \\
\quad(3-4)\end{array}$ & $\begin{array}{l}2,00 \pm 0,00 \\
\quad(2-2)\end{array}$ \\
\hline SAB & $\begin{array}{l}182 \pm 11,49 \\
(156-210)\end{array}$ & $\begin{array}{c}181,43 \pm 10,35 \\
(162-214)\end{array}$ & $\begin{array}{c}173,33 \pm 6,93 \\
(164-183)\end{array}$ & $\begin{array}{c}166,60 \pm 11,13 \\
(151-194)\end{array}$ \\
\hline SMDL & $\begin{array}{l}166 \pm 13,76 \\
(136-191)\end{array}$ & $\begin{array}{c}171,68 \pm 14,53 \\
(140-200)\end{array}$ & $\begin{array}{c}145,75 \pm 8,36 \\
(136-164)\end{array}$ & $\begin{array}{c}153,8 \pm 14,26 \\
(137-187)\end{array}$ \\
\hline SMDH & $\begin{array}{c}31,13 \pm 4,22 \\
(23-43)\end{array}$ & $\begin{array}{c}32,60 \pm 4,02 \\
(26-45)\end{array}$ & $\begin{array}{c}30,33 \pm 3,75 \\
(25-38)\end{array}$ & $\begin{array}{l}24,40 \pm 2,76 \\
(21-30)\end{array}$ \\
\hline SVL & $\begin{array}{c}70,85 \pm 14,61 \\
(47,17-113,1)\end{array}$ & $\begin{array}{c}77,57 \pm 16,10 \\
(45,52-103,43)\end{array}$ & $\begin{array}{c}84,00 \pm 26,69 \\
(43,12-119,46)\end{array}$ & $\begin{array}{c}66,83 \pm 14,02 \\
(35,82-82,62)\end{array}$ \\
\hline $\mathrm{TL}$ & $\begin{array}{l}70,34 \pm 13,32 \\
(47,3-101,5)\end{array}$ & $\begin{array}{c}73,51 \pm 18,35 \\
(37,52-154,51)\end{array}$ & $\begin{array}{c}84,06 \pm 24,39 \\
(44,62-107,48)\end{array}$ & $\begin{array}{c}61,23 \pm 14,87 \\
(36,67-84,72)\end{array}$ \\
\hline MAX & $\begin{array}{c}17,00 \pm 3,84 \\
(10,91-29,1)\end{array}$ & $\begin{array}{c}19,95 \pm 4,42 \\
(11,38-28,56)\end{array}$ & $\begin{array}{c}20,19 \pm 7,28 \\
(9,43-30,00)\end{array}$ & $\begin{array}{c}16,14 \pm 3,32 \\
(9,09-20,10)\end{array}$ \\
\hline $\mathrm{HL}$ & $\begin{array}{c}20,11 \pm 4,07 \\
(13,55-31,20)\end{array}$ & $\begin{array}{c}22,27 \pm 4,65 \\
(13,20-31,76)\end{array}$ & $\begin{array}{c}24,91 \pm 7,99 \\
(12,68-35,65)\end{array}$ & $\begin{array}{c}18,37 \pm 3,98 \\
(10,05-23,90)\end{array}$ \\
\hline DEO & $\begin{array}{l}8,40 \pm 1,97 \\
(5,3-13,9)\end{array}$ & $\begin{array}{c}10,12 \pm 2,40 \\
(5,43-13,97)\end{array}$ & $\begin{array}{c}10,72 \pm 4,22 \\
(4,84-16,96)\end{array}$ & $\begin{array}{c}7,97 \pm 2,09 \\
(4,17-11,48)\end{array}$ \\
\hline DEN & $\begin{array}{l}5,59 \pm 1,11 \\
(3,6-8,12)\end{array}$ & $\begin{array}{c}6,11 \pm 1,26 \\
(3,56-9,02)\end{array}$ & $\begin{array}{c}6,18 \pm 1,81 \\
(3,34-8,27)\end{array}$ & $\begin{array}{c}4,58 \pm 0,84 \\
(2,78-5,72)\end{array}$ \\
\hline DPOEF & $\begin{array}{l}12,15 \pm 2,28 \\
(8,13-18,3)\end{array}$ & $\begin{array}{l}13,20 \pm 2,73 \\
(7,8-20,54)\end{array}$ & $\begin{array}{c}14,54 \pm 4,61 \\
(6,48-20,47)\end{array}$ & $\begin{array}{c}10,78 \pm 1,82 \\
(6,86-12,86)\end{array}$ \\
\hline DIS & $\begin{array}{c}14,80 \pm 2,54 \\
(9,4-21,6)\end{array}$ & $\begin{array}{c}15,78 \pm 2,92 \\
(9,10-20,61)\end{array}$ & $\begin{array}{c}17,14 \pm 4,71 \\
(10,04-23,50)\end{array}$ & $\begin{array}{c}12,94 \pm 2,71 \\
(7,78-17,86)\end{array}$ \\
\hline SGF & $\begin{array}{l}24,14 \pm 4,79 \\
(16,5-37,3)\end{array}$ & $\begin{array}{c}26,77 \pm 5,45 \\
(15,29-36,82)\end{array}$ & $\begin{array}{c}28,95 \pm 8,66 \\
(15,02-40,84)\end{array}$ & $\begin{array}{c}20,85 \pm 4,30 \\
(12,18-26,76)\end{array}$ \\
\hline
\end{tabular}

Due to the fact that the morphometric characters based Principal Component Analysis (PCA) did not resolve discrete groups for any of the Diplolaemus species, these were not used in the subsequent analyzes (Fig. 5). In this analysis Factor 1 (Eigenvalue $=3.285$ ), explained $54.8 \%$ of the total variation and Factor 1 and 2 explained together $71.3 \%$. $($ Eigenvalue $=0.991)$. Although the total variance explained by this analysis was high, the distribution of individuals values in the two factors did not conform discrete groups. The
PCA based on meristic characters identified three discrete groups. Factor 1 explained $39.14 \%$ of the total variation, and Factor 1 (Eigenvalue $=4.696)$ and Factor 2 (Eigenvalue $=1.696$ ) explained together $53.27 \%$ of the total variation. In this axis, the variables with highest factor loading were SSoSp (factor loading $=-0.8091$ ), SNG (factor loading = - 0.760), INPM (factor loading = - 0.736), and SEE (factor loading $=-0.739$ ). The variables for the second factor with the highest factor loading were PMS (factor loading = 0.637) 
and SPL (factor loading $=-0.551$ ). The scatterplot of the first two components permitted separation of $D$. darwinii from $D$. sexcinctus + D. leopardinus + D. bibronii (Fig. 6). Factor 2 separated the individuals of $D$. sexcinctus from those of the other three species. D. leopardinus and D. bibronii overlap along both axes. Therefore, there is a greater difference at the scalation level for $D$. darwinii, with respect to the other species. On the other hand, D. leopardinus and D. bibronii are very similar.

To test the significance of the differences between species in meristic variables, a multivariate analysis of the variance for the total set of individuals was conducted. Differences were highly significant (Lambda of Wilks $=0.0082 ; F_{(36,245)}$ $=27.876 ; p<0.001$ ). The univariate tests of Tukey (Table 2) provide a greater number of significant differences for the comparisons involving $D$. darwinii, what is in agreement with the clear separation of this species in the PCA. On the other hand, when D. leopardinus is compared with $D$. bibronii, species that were indistinguishable in the PCA, significant differences were only found for the SPL and
SMDL variables. The comparison $D$. bibronii - D. sexcinctus provided significant differences for seven variables (SPL, SSoSp, SNG, INPM, SEE, PMS and PSF), while the species D. sexcinctus provided significant differences with respect to D. leopardinus in 6 characters (SSoSp, SNG, INPM, PMS, SAB, and SMDL).

The discriminant function and its efficacy in assigning the individuals of each one of the species of Diplolaemus is summarized in Tables 3 and 4 respectively. Three discriminant canonic functions were generated (Table 3), each one with eight variables of scalation, which provided a high discrimination power. The classification matrix (Table 4) indicates that a high percentage of the individual assignments were correct $(96 \%$ of the total). The values are high for the species D. sexcinctus $(96.5 \%), D$. bibronii $(97.9 \%)$, and $D$. darwinii $(100 \%)$. However, the discriminant functions were not as successful for individual assignment of the individuals of D. leopardinus; only $83.4 \%$ of these were correctly assigned, while the remaining $15.6 \%$ of the individuals were all wrongly assigned to the species $D$. bibronii.

TABLE 2. Results of Tukey post-hoc test of $\log _{10}$ transformed meristic characters for all species of Diplolaemus. (1) D. sexcinctus; (2) D. bibronii; (3) D. leopardinus; (4) D. darwinii. Values in the table are pairwise comparison probabilities. See text for variable abbreviations.

TABLA 2. Resultados del test post-hoc de Tukey de los caracteres merísticos transformados a $\log _{10}$ para todas las especies de Diplolaemus. (1) D. sexcinctus; (2) D.bibronii; (3) D. leopardinus; (4) D. darwinii. Los valores de la tabla son las probabilidades de las comparaciones pareadas. Ver texto para la abreviación de las variables.

\begin{tabular}{lcccccc}
\hline & \multicolumn{5}{c}{ Species comparison } \\
\cline { 2 - 7 } Variable & $1-2$ & $1-3$ & $1-4$ & $2-3$ & $2-4$ & $3-4$ \\
\hline SPL & 0.041 & 0.694 & $<0.001$ & 0.037 & $<0.001$ & $<0.001$ \\
INF & 0.980 & 0.940 & $<0.001$ & 0.988 & $<0.001$ & $<0.001$ \\
SNR & 0.343 & 0.319 & $<0.001$ & 0.910 & $<0.001$ & $<0.001$ \\
SSoSp & $<0.001$ & 0.007 & $<0.001$ & 0.874 & $<0.001$ & $<0.001$ \\
SNG & 0.010 & $<0.001$ & $<0.001$ & 0.263 & $<0.001$ & $<0.001$ \\
INPM & $<0.001$ & $<0.001$ & 0.014 & 0.773 & $<0.001$ & $<0.001$ \\
SEE & $<0.001$ & 0.083 & $<0.001$ & 0.078 & $<0.001$ & $<0.001$ \\
PMS & $<0.001$ & $<0.001$ & 0.943 & 0.999 & $<0.001$ & $<0.001$ \\
SMDH & 0.206 & 0.999 & $<0.001$ & 0.544 & $<0.001$ & $<0.001$ \\
PSF & 0.026 & 0.574 & 0.265 & 0.963 & 0.998 & 0.956 \\
SAB & 0.985 & 0.046 & $<0.001$ & 0.085 & $<0.001$ & 0.396 \\
SMDL & 0.237 & $<0.001$ & 0.035 & $<0.001$ & $<0.001$ & 0.405 \\
\hline
\end{tabular}


Gayana 74(1), 2010

TABLE 3. Results of discriminant function analyses of meristic variation in all species of the genus Diplolaemus. See text for variable abbreviations.

Tabla 3. Resultados de los análisis de función discriminante de la variación merística de todas las especies del género Diplolaemus. Ver texto para la abreviación de las variables.

\begin{tabular}{|c|c|c|c|c|}
\hline \multicolumn{4}{|c|}{ Canonical scores of group means } & \multirow{3}{*}{$\begin{array}{c}\text { Discriminant function } \\
\text { (variables } \log _{10} \text { transformed) }\end{array}$} \\
\hline \multirow[b]{2}{*}{ Species } & \multicolumn{3}{|c|}{ Canonical variable } & \\
\hline & 1 & 2 & 3 & \\
\hline D. sexcinctus & -3.855 & -1.270 & -0.018 & $\begin{array}{l}\text { (1) }-0.013 \mathrm{SPL}+0.012 \mathrm{INF}+0.173 \mathrm{SNR}-0.041 \mathrm{SSoSp}+ \\
0.176 \mathrm{SNG}-0.133 \mathrm{PSF}+0.154 \mathrm{INPM}+0.300 \mathrm{SEE}+0.962 \mathrm{PMS} \\
+0.127 \mathrm{SAB}-0.115 \mathrm{SMDL}-0.103 \mathrm{SMDH}\end{array}$ \\
\hline D. bibronii & 4.147 & 0.285 & -0.422 & $\begin{array}{l}\text { (2) }-0.301 \mathrm{SPL}-0.403 \mathrm{INF}-0.725 \mathrm{SNR}+0.006 \mathrm{SSoSp}- \\
0.016 \mathrm{SNG}+0.271 \mathrm{PSF}+0.174 \mathrm{INPM}-0.216 \mathrm{SEE}+0.175 \mathrm{PMS} \\
-0.271 \mathrm{SAB}+0.113 \mathrm{SMDL}-0.089 \mathrm{SMDH}\end{array}$ \\
\hline D. leopardinus & 4.216 & -0.019 & 1.880 & $\begin{array}{l}(3)+0.506 \mathrm{SPL}-0.315 \mathrm{INF}-0.160 \mathrm{SNR}+0.102 \mathrm{SSoSp}+ \\
0.256 \mathrm{SNG}-0.149 \mathrm{PSF}+0.231 \mathrm{INPM}-0.190 \mathrm{SEE}-0.051 \mathrm{PMS} \\
-0.193 \mathrm{SAB}-0.788 \mathrm{SMDL}-0.079 \mathrm{SMDH}\end{array}$ \\
\hline D. darwinii & -5.987 & 6.017 & 0.100 & \\
\hline
\end{tabular}

TABLE 4. Classification matrix obtained from the discriminant functions shown in Table 3.

TABLE 4. Matriz de clasificación obtenida de las funciones discriminantes mostradas en la Tabla 3.

\begin{tabular}{|c|c|c|c|c|c|c|}
\hline & \multirow[b]{2}{*}{ Species $(N)$} & \multicolumn{4}{|c|}{ Predicted species } & \multirow[b]{2}{*}{$\%$ correct } \\
\hline & & (1) & (2) & (3) & (4) & \\
\hline (1) & D. sexcinctus $(42)$ & 41 & 1 & 0 & 0 & 97.6 \\
\hline (2) & D. bibronii (40) & 0 & 38 & 2 & 0 & 95.0 \\
\hline (3) & D. leopardinus (9) & 0 & 2 & 7 & 0 & 77.8 \\
\hline \multirow[t]{2}{*}{ (4) } & D. darwinii (7) & 0 & 0 & 0 & 7 & 100 \\
\hline & Total & 41 & 41 & 9 & 7 & 94.9 \\
\hline
\end{tabular}


With respect to the coloration, the dorsal design clearly distinguishes the four species of the genus (Fig. 4). Even though $D$. sexcinctus can present variations in tonality, the design that is superimposed in the background is constant. The dorsal color pattern of $D$. sexcinctus consists in six transverse bands extending from the shoulder to the pelvic region (Figs. 2B-C, 3D; Cei et al. 2003). Each half of a single band forms a "butterfly wing" shape, and at the posterior margin of each "wing" there is a light blue spot. The body's background color is gray-ochre, and the head is covered with dark brown spots. In the mouth, there are brown dots. There is a clear difference in color patterns between $D$. sexcinctus and $D$. leopardinus; in the latter the background is yellowish with small brown spots without the typical butterfly design present in $D$. sexcinctus. In $D$. darwinii the dorsal pattern is very irregular and characterized by a dendritic dark brown design over a gray-ochre background (Fig. 4). Finally, in $D$. bibronii the matrix color is grey-orange overlaid by symmetric brownish bands, and each band is bordered by a yellowish semicircle.
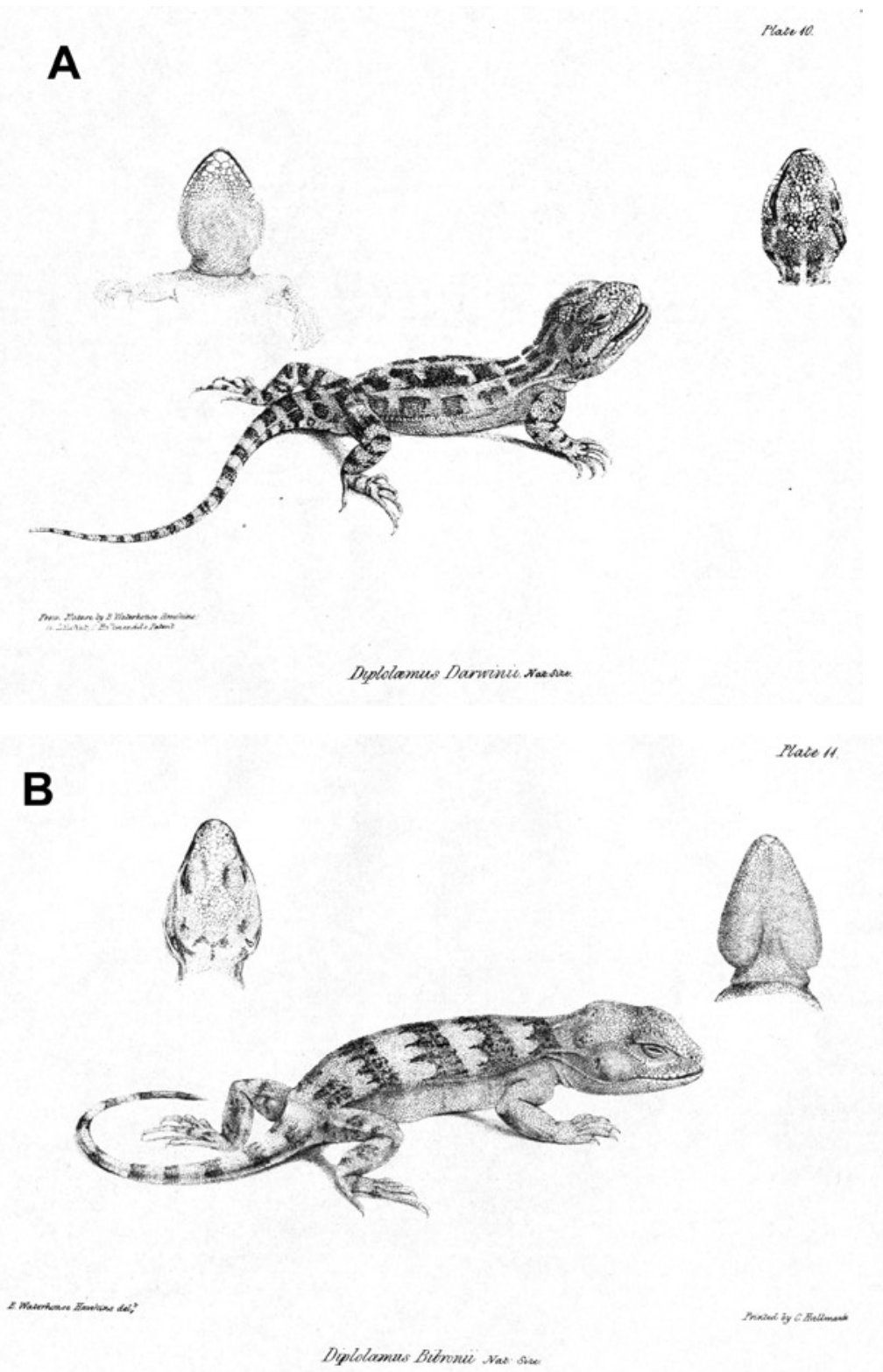

FIGURE 1. Original plates from Bell (1843), showing the species of Diplolaemus described form the expedition of Charles Darwin. (A) D. darwinii, (B) D. bibronii.

Figura 1. Láminas originales del capítulo de Bell (1843), mostrando las especies de Diplolaemus descritas en la expedición de Charles Darwin. (A) D. darwinii, (B) D. bibronii. 


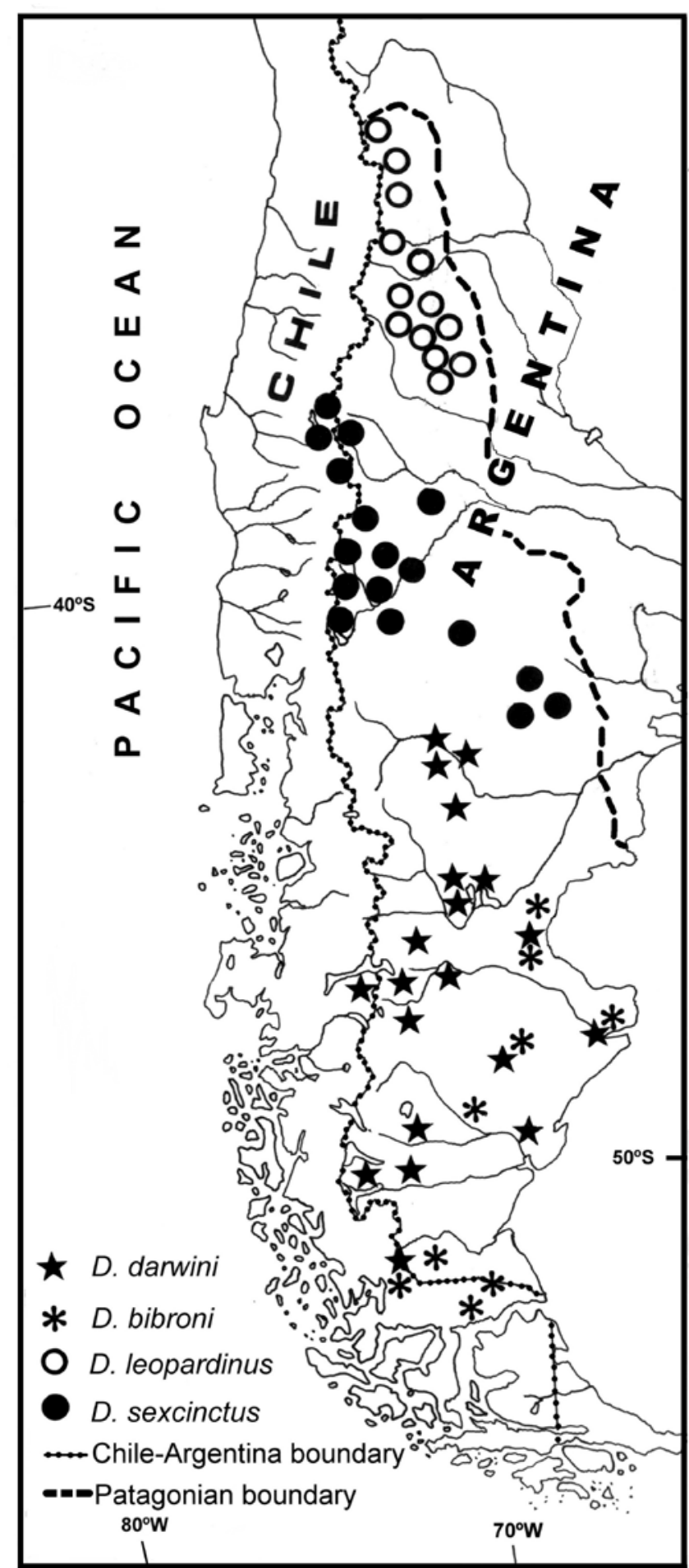

Figure 2. Map showing the recording localities of four species of Diplolaemus (modified from Cei 1986). Patagonian boundaries (dashed lines), based on Cei (1979).

Figura 2. Sitios de registro para las especies de Diplolaemus (modificado de Cei 1986). Límites de Patagonia (línea segmentada), basados en Cei (1979).

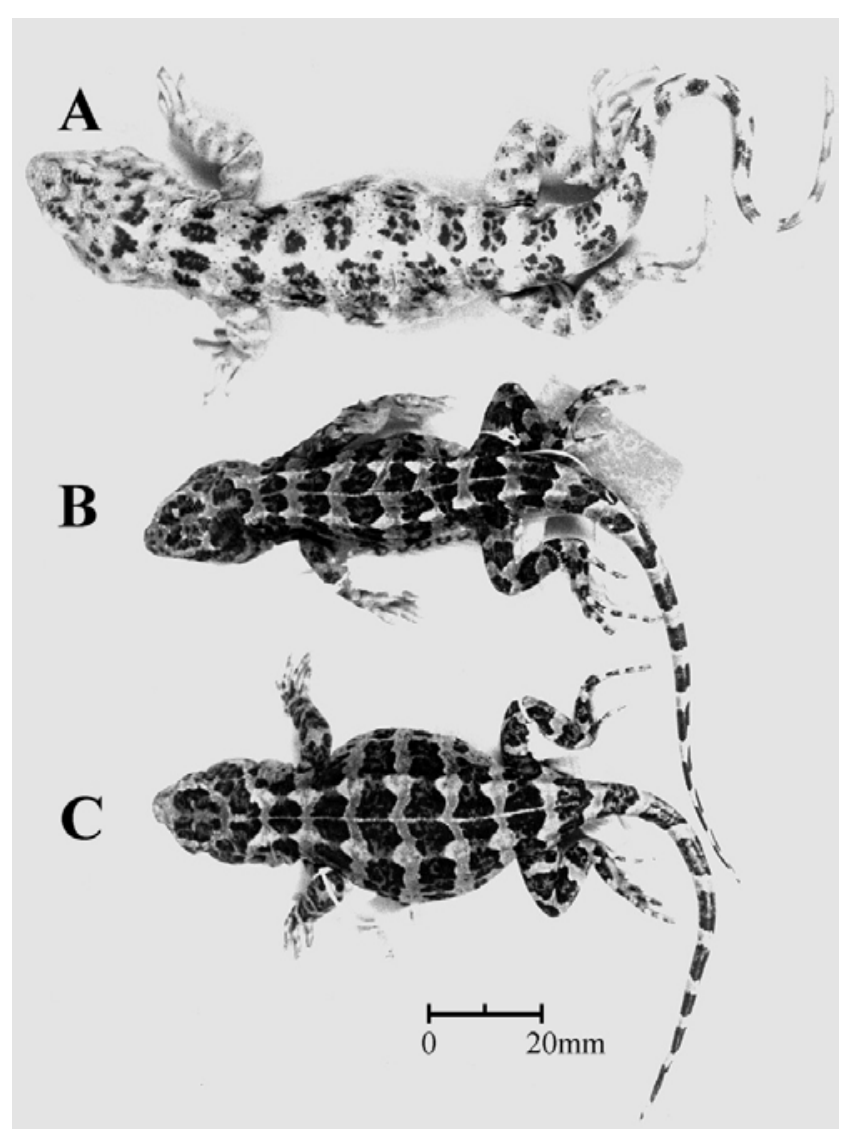

Figure 3. Dorsal view of (A) holotype of D. leopardinus (ZMB13395), (B) adult male (MZUC-23303), and (C) adult female (MZUC-23302) of Diplolaemus sexcinctus (Chilean populations).

FIGURA 3. Vista dorsal (A) del holotipo de D. leopardinus (ZMB13395), (B) de macho adulto (MZUC-23303) y (C) de hembra adulta (MZUC-23302) de D. sexcinctus (poblaciones chilenas).

Distribution OF THE SPECiEs (Fig. 2). Diplolaemus sexcinctus is known from the Argentinean provinces of Neuquén, Chubut, and Río Negro, and in the Patagonian extensions across the Andes into neighboring valleys in the upper part of the Chilean Biobío River basin. Following our proposed taxonomic status, $D$. leopardinus is restricted to the Argentinian Province of Mendoza. Diplolaemus bibronii is widely distributed across Patagonian landscapes in the Argentinian provinces of Chubut and Santa Cruz, and southeastern Chile. Finally, D. darwinii is the southernmost species of the genus, being known from the provinces of Chubut and Santa Cruz, Argentina, and from the Province of Magallanes in Chile (Fig. 2). 


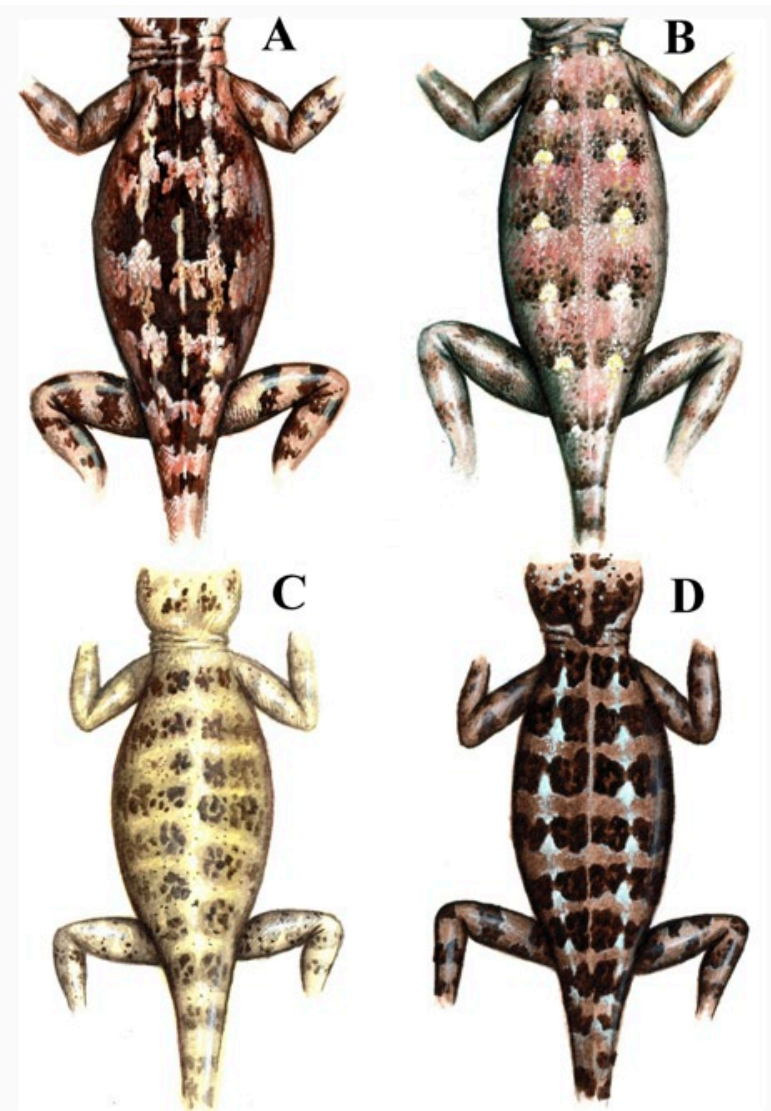

FIgURE 4. Comparisons of the dorsal pattern of four species of Diplolaemus. (A) D. darwinii (BMNH-0064), (B) D. bibronii (MZUC23328), (C) D. leopardinus (ZMB-13395), and (D) D. sexcinctus (MZUC-23303).

Figura 4. Comparación de los patrones dorsales de cuatro especies de Diplolaemus. (A) D. darwinii (BMNH-0064), (B) D. bibronii (MZUC-23328), (C) D. leopardinus (ZMB-13395), y (D) D. sexcinctus (MZUC-23303).

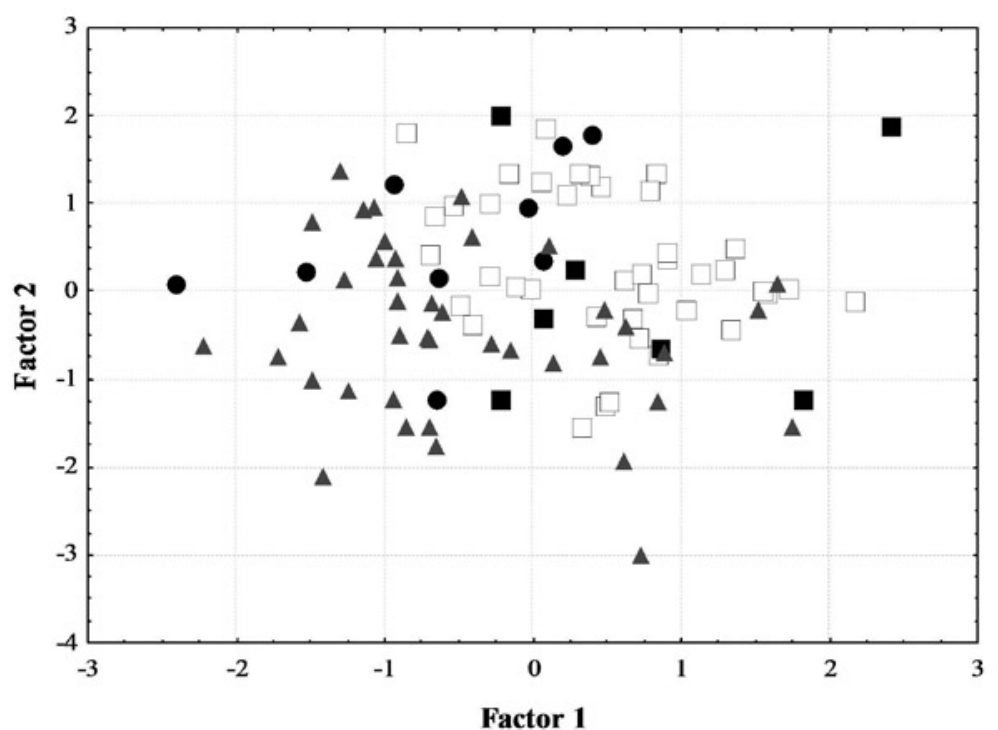

FIGURE 5. Scatter diagram of the first and second principal component scores generated by principal component analysis of morphometric characters in the species of Diplolaemus. Gray triangles, D. sexcinctus; white squares, $D$. bibronii; black circles, D. leopardinus; black squares, $D$. darwinii.

FIgURA 5. Diagrama de dispersión de los valores del primer y segundo componente principal generado por análisis de componentes principales de los caracteres de variables morfométricas en las especies de Diplolaemus. Triángulos grises, D. sexcinctus; cuadrados blancos, D. bibronii; círculos negros, D. leopardinus; cuadrados negros, D. darwinii. 
Gayana 74(1), 2010

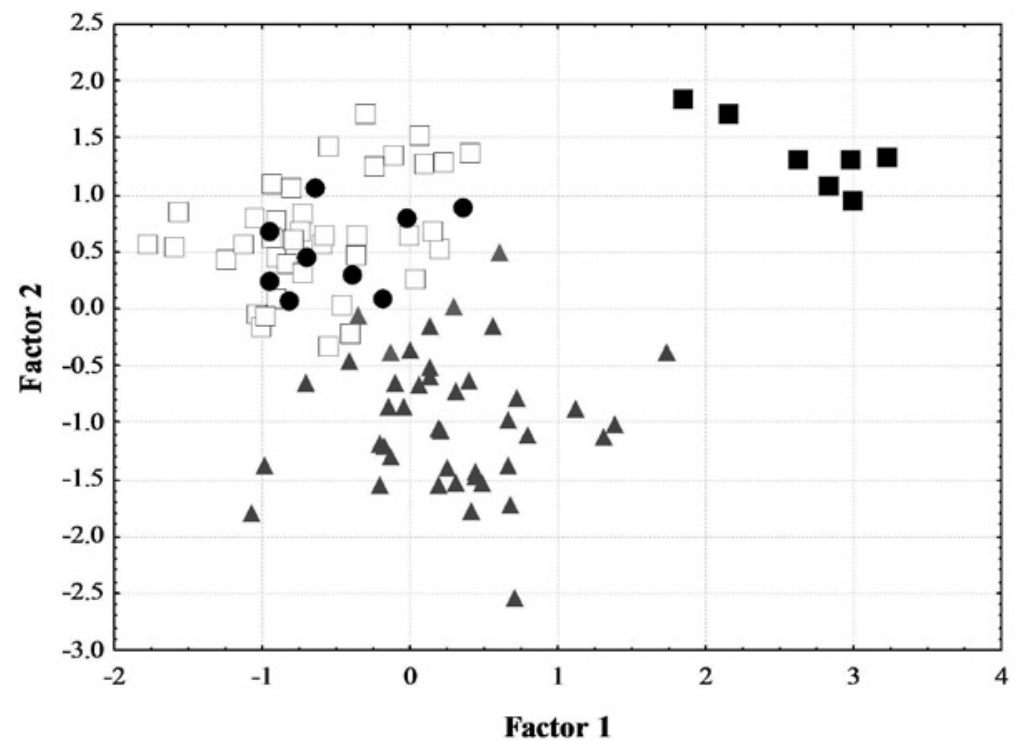

FIGURE 6. Scatter diagram of the first and second principal component scores generated by principal component analysis of scalation characters in the species of Diplolaemus. Gray triangles, D. sexcinctus; white squares, D. bibronii; black circles, D. leopardinus; black squares, D. darwinii.

FIgURA 6. Diagrama de dispersión de los valores del primer y segundo componente principal generado por análisis de componentes principales de los caracteres de escamación en las especies de Diplolaemus. Triángulos grises, D. sexcinctus; cuadrados blancos, D. bibronii; círculos negros, $D$. leopardinus; cuadrados negros, D. darwinii.

\section{DISCUSSION}

Multivariate comparisons in the PCA show that there is a high degree of phenotypic similarity among species of the genus Diplolaemus. Within the context of this high similarity, Diplolaemus darwinii is the most distinct phenetically, both in color pattern as well as in meristic characters. This higher distinction of $D$. darwinii was reported previously by Cei (1975) based on serological characters. In contrast to this observation, the other three species show moderate to extensive overlap in the magnitude of the morphometric variables analyzed, which makes their discrimination difficult and has generated most of the taxonomic confusion. The conservative morphology shown by some lizard species has been explained because of phylogenetic restriction or strong selection pressures (Malhotra \& Thorpe 1994; Pianka \& Vitt 2003; Losos 2009); any of these this could be the mechanism driving the similar morphology among Diplolaemus species.

An additional source of taxonomic confusion is the lack of information on the geographic provenience of the holotype of $D$. leopardinus, which is necessary to delimit the real geographical distribution of this taxon. However, it is important to highlight the itinerary of the expedition that have originated the Plate collections, during which the holotype was obtained and which did not include localities close to the geographic distribution of Chilean D. leopardinus populations from the Andes sensu DonosoBarros (1965), which are assigned to D. sexcinctus after this study. Cei et al. (2003) described D. sexcinctus based on the "alto patagónica" populations; its holotype is from Río Negro, Argentina. The authors included within this species the populations from Mendoza, and citing Donoso Barros (1966) maintained the original interpretation that $D$. leopardinus distributes in Laguna del Laja, Chile. Cei et al. (2003) wrote "The third species of the genus, Diplolaemus leopardinus Werner, is a Chilean lizard, scarcely and poorly cited for its still uncertain areas in Neuquén. Recently, preliminary commentaries point out its possible relationships with the Argentinean six-banded populations, evidently sympatric in such a bordering zone. Thus, we are dealing with not yet solved taxonomic and nomenclatural problems, wanting Chilean cooperation, but impossible to be developed in our present research on Argentinean taxa". While, Cei et al. (2003) in their Figure 1 assigned populations from Mendoza to D. sexcinctus, we here conclude that samples should be assigned to D. leopardinus. Meanwhile, Pincheira-Donoso et al. (2007), in an article on Liolaemus species, misunderstood the taxonomic discussion of Cei et al. (2003) and wrongly wrote "...the populations identified as Diplolaemus leopardinus...by Donoso-Barros (1974) at Laguna del Laja (Chile), were recently described as the new species Diplolaemus sexcinctus (Cei /et al/. 2003)". 
After Cei et al. (2003), ours is the first taxonomic study focusing in Diplolaemus that includes individuals from Laguna del Laja, Chile. Then, this is to be considered the first assignment to $D$. sexcinctus of populations previously considered to belong to D. leopardinus.

On the other hand, it is possible that D. leopardinus inhabits the area near the Argentinean-Chilean border at the latitude of Santiago, where Cei (1986) recognizes the "Sudmendocinan form". Indeed, when comparing the dorsal design of the holotype of $D$. leopardinus, lizards from Mendoza, and Plate 4 of Cei (1986), and considering the results of the discriminant analysis, which included the holotype of $D$. leopardinus, it is reasonable to propose that $D$. leopardinus inhabits the Mendoza region of Argentina. The principal difference between this species and D. sexcinctus is the number of post-mental scales and the dorsal color pattern. Thus, the three taxa source of taxonomic confusion, $D$. bibronii, D. leopardinus, and D. sexcinctus, can all be clearly discriminated from each other on the basis of color pattern in combination with post-mental scale counts.

Diplolaemus sexcinctus is often found in open shrubby and herbaceous habitats; however, this species also occurs in forests of Araucaria araucana (Cei 1970). This fact highlights the concordance of the distribution of this species with that of a forest that in the past (early Cenozoic), showed a wider distribution, including for example, the large Altiplanicie Central in Patagonia (Cei 1979). It is probable that $D$. sexcinctus originated as a species linked to this type of forest, and later colonized more exposed micro-habitats of volcanic origin, such as the slopes of the Antuco Volcano in the Chilean Laguna del Laja National Park. Some of the assigned populations of this species are found in volcanic areas farther north, near the Nevados de Chillán, located outside the range of Araucaria araucana. This proposition may be rigorously tested by a detailed phylogeographic study of D. sexcinctus.

Cei (1979) proposed a zoogeographical subdivision of Patagonia into two regions based on its herpetofauna. Diplolaemus has a current distribution that is almost completely concordant with the geographical extension of the Patagonian province. However, of the four species of this genus, only $D$. sexcinctus and $D$. leopardinus are exclusive to the hypothesized ancient (southern) Patagonian region. D. bibronii is distributed predominantly in the southern Patagonian region, but the northern limit of its distribution extends to mid-latitudes of Patagonia (Cei 1986). The only species exclusive to Austral Patagonia is D. darwinii, and according to Cei (1979), this region corresponds to a distinct biogeographical unit as indicated by its herpetofauna. $D$. darwinii presents keeled caudal scales that according to Etheridge \& Williams (1985) it is a plesiomorphic condition in the genus. Considering the species geographical distributions, it is reasonable to hypothesize that $D$. darwinii or its ancestor must have separated early in the history of the genus, and that this speciation event could have occurred in the southern region of Patagonia. The origin of the remaining Diplolaemus species may have been associated with a northward advance of the clade, associated with periodic isolation and expansion events as a consequence of glaciation cycles. This hypothesis is testable as it predicts a south-to-north phylogenetic sequence of relationships, which would culminate in the recent origin of high Andean populations $D$. sexcinctus and D. leopardinus in the Provincia of Mendoza, Argentina.

\section{ACKNOWLEDGMENTS}

The following people and institutions facilitated individuals of Diplolaemus: F. Troncoso (Museo Regional de Concepción); M.I. Christie (Sociedad Naturalista Andino Patagónica); J. Langone (Museo de Historia Natural de Montevideo); C. McCarthy (British Museum of Natural History); R. Günther (Museum für Naturkunde); H. Núñez (Museo Nacional de Historia Natural de Santiago de Chile); E. Pereyra (Instituto de Biología Animal. Universidad Nacional de Cuyo). A.R. Young, H. Ibarra-Vidal and F. Torres helped during field work. E.M. Habit provided comments on the manuscript and helped obtaining part of the material in the Laguna del Laja National Park. Two anonymous reviewers provided valuable suggestions on an earlier version of this contribution. Financial support was provided by the U.S. National Science Foundation (OISE 0530267 to PFV), Universidad de Concepción's Research Division grants 92.38.24-1, 96.113.040-1 and.205.113.0671sp, and FONDECYT 1090664. Collecting permits in Chile were provided by CONAF.

\section{BIBLIOGRAPHY}

Anderson, L.G. 1898. List of Reptiles and Batrachians collected by the Swedish Expedition to Tierra del Fuego. 1895-1896 under direction of Otto Nordenskiöl. Oversight af Kongl VetenskapsAkademiens Forhandlingar. 7:457-462.

BeLl, T. 1843. Reptiles. In: Darwin C. The Zoology of the Voyage of the H.M.S. "Beagle", under command of Captain Fitzroy, R.N. during the years 1832-1836, pp. 1-51. Smith Elder Publish. London.

Boulenger, G.A. 1885. Catalogue of the Lizards in the British Museum (Natural History). Second Edition. 2:xiii $+497 \mathrm{pp}$.

CEI, J.M. 1970. Fluctuaciones biocenóticas y relictos herpetológicos de la planicie de Lonco-Luan 
(Neuquén). Acta Zoológica Lilloana 27:193-200.

CEI, J.M. 1971. Herpetología Patagónica 2. Notas sobre la distribución geográfica del género Diplolaemus. Physis 30(80):471-474.

CEI, J.M. 1975. Herpetología Patagónica 11. Diferenciación serológica de Diplolaemus darwinii y Diplolaemus bibronii en poblaciones alo-simpátridas. Physis 34(89):209-210.

CEI, J.M. 1979. The Patagonian Herpetofauna. En: The South American Herpetofauna: Its Origin, Evolution and Dispersal. Duellman, W., Ed. Monographies of the Museum of Natural History. University of Kansas 7:29-54.

CEI, J.M. 1986. Reptiles del Centro-Oeste y Sur de la Argentina. Herpetofauna de las Zonas Aridas y Semiáridas. Monografie 4. Museo Regionale di Scienze Naturali. Torino. 526 pp.

Cei, J.M., J. Scolaro \& Videla, F. 2003. A taxonomic revision of recognized Argentine species of the leiosaurid genus Diplolaemus (Reptilia: Squamata: Leiosauridae). Facena 19:87-106.

Donoso-Barros, R. 1965. El género Diplolaemus Bell en Sudamérica. Anais 2. Congreso Latinoamericano de Zoología. São Paulo. 219-225.

Donoso-Barros R. 1966. Reptiles de Chile. Ediciones de la Universidad de Chile. Santiago. 458 pp.

Donoso-Barros, R. \& M. Codoceo 1962. Reptiles de Aysén y Magallanes. Boletín del Museo Nacional de Historia Natural 27(1):1-45.

Donoso-Barros, R. 1974. Notas herpetológicas. Boletín de la Sociedad de Biología de Concepción. 47: 285-287.

Etheridge, R. \& Williams, E. 1985. Notes on Pristidactylus (Squamata: Iguanidae). Breviora 483:1-18.

Greene, H.W. 1995. Nonavian Reptiles as Laboratory Animals. ILAR Journal. Fish, Amphibians and Reptiles 37(4).

IbArgüEngoytia, N. \& J.A. Schulte 2001. Geographic distribution, Diplolaemus darwinii. Herpetological Review 32(1):57.

Lamborot, M. \& N. Diaz 1987. A new species of Pristidactylus (Sauria: Iguanidae) from Central Chile and comments on the Speciation in the genus. Journal of Herpetology 21(1):29-37.

Losos, J.B. 2009. Lizards in an Evolutionary Tree. Ecology and Adaptive Radiations of Anoles. University of California Press. California, USA. 507 pp.

Mahotra, A. \& R.S. Thorpe 1994. Parallels between island lizards suggests selection on mitochondrial DNA and morphology. Proceedings: Biological Sciences 257 (1348): 37-42.

Peters, J.A. \& R. Donoso-Barros, 1970. Catalogue of the Neotropical Squamata. Part 2. Lizards and Amphisbaenians. Bulletin of the US National Museum 297:1-293.
PianKa, E.R. \& L.J. VitT 2003. Lizards. Windows to the Evolution of Diversity. University of California Press. California, USA. 332 pp.

Pincheira-Donoso, D., A. Scolaro \& J.A. Schulte 2007. The limits of polymorphism in Liolaemus rothi: molecular and phenotypic evidence for a new species of the Liolaemus boulengeri clade (Iguanidae, Liolaemini) from boreal Patagonia of Chile. Zootaxa 1452:25-42.

Stejneger, L. 1909. Batrachians and Reptiles of the Princeton University Expedition to Patagonia, 18961899. Princeton, New Jersey (Zoology) 3:221-224.

Werner, F. 1898. Die Reptilien und Batrachien der Sammlung Plate. Zoologische Zoologischen Jahrbüchern Supplement 4:244-278.

\section{ApPendix 1}

List of specimens examined in the present study. Specimens are deposited in the following institutions: Alemania: Zoologischen Museum Berlin (ZMB); Argentina: Instituto de Biología Animal, Universidad Nacional de Cuyo (IBA) and Patagonian Andean Naturalist Society of San Carlos de Bariloche (MIC); Chile: Museo de Zoología de la Universidad de Concepción (MZUC), Museo Nacional de Historia Natural de Santiago (MNHN) and Museo Regional de Concepción (MCR); Inglaterra: British Museum Natural History (BMNH); and Uruguay: Museo Nacional de Historia Natural de Montevideo (MNHM).

Diplolaemus darwinii Bell, 1843: BMNH-0064, leptotype, adult male, Puerto Deseado, Puerto Deseado Department, Santa Cruz Province, Argentina, 1833. MNHN-CN1040, adult female, Ultima Esperanza Province, Magallanes y la Antártica Chilena Region, Chile, 12-I-1953. IBA9241, 9242, adult males, Bosque Petrificado, Puerto Deseado Department, Santa Cruz Province, Argentina, I-1973. IBA612, juvenile male, Estancia Esperanza, Santa Cruz Province, Argentina, 15-I-1970. IBA5221, 5222, adult females, $10 \mathrm{~km}$ north of Gobernador Gregores, Río Chico Department, Santa Cruz Province, Argentina (no date). IBA5223, juvenile female, 10 $\mathrm{km}$ north of Gobernador Gregores, Río Chico Department, Santa Cruz Province, Argentina. IBA6131, adult male, Estancia Carlota, Santa Cruz Province, Argentina, 20-I-1970. IBA6132, juvenile, Estancia Carlota, Santa Cruz Province, Argentina, 20-I-1970.

Diplolaemus bibronii Bell, 1843: BMNH-0013, leptotype, adult male, Puerto Deseado, Puerto Deseado Department, Santa Cruz Province, Argentina, 1833. BMNH-0010, 0011, paraleptotypes, adult females, Puerto Deseado, Puerto Deseado Department, Santa Cruz Province, Argentina, 1833. BMNH-0012, paraleptotype, adult male, Puerto 
Deseado, Puerto Deseado Department, Santa Cruz Province, Argentina, 1833. MCR-RO331, adult female, Chile Chico, General Carrera Province, Aisén del General Carlos Ibáñez del Campo Region, 15-I-1982. MZUC-6978, adult male, Santa Cruz Province, Argentina, I- 1985. MZUC-8968, adult female, Comodoro Rivadavia, Escalante Department, Chubut Province, Argentina, 29-X-1968. MZUC-23202, 23204, adult males, Chile Chico, General Carrera Province, Aisén del General Carlos Ibáñez del Campo Region, Chile, 24-II-1977. MZUC-23203, adult male, Río Mayo, Río Senguer Department, Chubut Province, Argentina, 27-II-1977. MNHM-01369, adult male, Punta Cavendish, Puerto Deseado, Puerto Deseado Department, Santa Cruz Province, Argentina, 9-XI-1965. MNHM-01654, 05823, adult males, Santa Cruz Province, Argentina, 23-I-1967. MNHM-03381, adult male, El Calafate, Lago Argentino Department, Santa Cruz Province, Argentina, 23-I-1967. MNHN-CN1502, adult female, Chile Chico, General Carrera Province, Aisén, del General Carlos Ibáñez del Campo Region, Chile, 15-XI-1983. MNHN-CN1501, 1503, 1505 adult males, Chile Chico, General Carrera Province, Aisén del General Carlos Ibáñez del Campo Region Chile, 5-XI-1983. MNHN-CN1743, adult female, Chile Chico, General Carrera Province, Aisén del General Carlos Ibáñez del Campo Region Chile, 22-X-1956. MNHN-CN1744, adult male, Chile Chico, General Carrera Province, Aisén del General Carlos Ibáñez del Campo Region Chile, 22-X1956. MZUC-23328 - 23330, adult males, road between Perito Moreno and Río Mayo, Río Senguer Department, Chubut Province, Argentina, 14-II-1991. MZUC-23331, adult female, Chile Chico, General Carrera Province, Aisén del General Carlos Ibáñez del Campo Region, Chile, 16II-1988. MZUC-23332, 23333, adult males, Chile Chico, General Carrera Province, Aisén del General Carlos Ibáñez del Campo Region, Chile, 16-II-1988. MZUC 053 Bosque Petrificado, Puerto Deseado Department, Santa Cruz Province, Argentina, 1981. IBA921, adult female, Meseta Canquel, Paso de Indios Department, Chubut Province, Argentina, I-1973. IBA909, adult male, Sierra Castillo, Chubut Province, Argentina, I-1973. IBA9141, juvenile, Caleta Olivia, Deseado Department, Santa Cruz Province, Argentina, I-1973. IBA9142, adult female, Caleta Olivia, Deseado Department, Santa Cruz Province, Argentina, I-1973. IBA8111, 8112, adult females, Meseta Canquel, Paso de Indios Department, Chubut Province, Argentina, I1972. IBA8113, juvenile, Meseta Canquel, Paso de Indios Department, Chubut Province, Argentina, I-1972. IBA838, adult male, road between Las Horquetas and El Sombrero, Chubut Province, Argentina, I-1972. IBA619, adult male, Valle Hermoso, Escalante Department, Chubut Province, Argentina, 22-I-1970. IBA915, adult male, road between Las Horquetas and El Sombrero, Chubut Province, Argentina, I1972. IBA922, adult female, Manantiales, Chubut Province, Argentina, I-1973. IBA910, adult male, Laguna Payahile,
Chubut Province, Argentina, I-1972. IBA513, adult female, Meseta Somuncurá, 9 de Julio Departament, Río Negro Province, Argentina, 18-11-1968. IBA8011, adult male, road between Paso de Indios and El Sombrero, Paso de Indios Department, Chubut Province, Argentina, 15-I-1972. IBA8012, adult female, road between Paso de Indios and El Sombrero, Paso de Indios Department, Chubut Province, Argentina, 15-I-1972. IBA8013, juvenile, road between Paso de Indios and El Sombrero, Paso de Indios Department, Chubut Province, Argentina, 15-I-1972. IBA451, juvenile, between Caleta Olivia and Fitz Roy, Deseado Department, Santa Cruz Province, Argentina, 26-12-1967. IBA6211, 6212, adult males, San Julián, Magallanes Department, Santa Cruz Province, Argentina, 13-I-1970. IBA923, adult male, Laguna Madre e Hija, Puerto Deseado Department, Santa Cruz Province, Argentina, I-1973.

Diplolaemus leopardinus (Werner), 1898: ZMB-13395, holotype, adult male, Santiago (in error), 1893-1895. IBA8121,8122, adult females, Payún, Malargüe Department, Mendoza Province, Argentina, 28-I-1972. IBA926, adult male, Tunuyán, Tunuyán Department, Mendoza Province, Argentina, 12-I-1973. IBA1177, adult male, $80 \mathrm{~km}$ south of Nihuil, San Rafael Department, Mendoza Province, Argentina, (no date). IBA7761, 7762, adult males, Payún, Malargüe Department, Mendoza Province, Argentina, 6XII-1971. IBA9251, 9252, adult females, Volcán Payún, Malargüe Department, Mendoza Province, Argentina, III-1973. IBA371, juvenile, Santa Clara, Tupungato Department, Mendoza Province, Argentina 12-I-1967. IBA911, juvenile, Volcán Payún, Malargüe Department, Mendoza Province, III-1973. IBA372, juvenile, El Portillo, Tunuyán Department, Mendoza Province, Argentina, 27-II1966.

Diplolaemus sexcinctus Cei, Scolaro \& Videla, 2003: MZUC23303, adult male, slope of Antuco Volcano, Laguna del Laja National Park ( $37^{\circ} 21^{\prime} \mathrm{S}-71^{\circ} 19^{\prime} \mathrm{W}$, at $1,300 \mathrm{~m}$ of altitude), Biobío Province, Biobío Region, Chile, collected by $\mathrm{P}$. Victoriano and E. Habit, 14-III-1992. MZUC-23302, adult female, slope of Antuco Volcano, Laguna del Laja National Park ( $37^{\circ} 21^{`} \mathrm{~S}-71^{\circ} 19^{`} \mathrm{~W}$, at 1,300 m of altitude), Biobío Province, Biobío Region, Chile, collected by P. Victoriano and J.C. Ortiz, 15-II-1987. MZUC-8765, 23324 -25, adult females, Petronquines, East of Laja Lake, Biobío Province, Biobío Region, Chile, collected by R. Donoso-Barros, 5-II1970. MZUC-8373, 23319, 23322, juveniles, Lonquimay, Pino Hachado, Malleco Province, Araucanía Region, Chile, collected by L. Peña, XII-1961. MZUC-11306, 23327, adult females, Marimeñuco, Alto Biobío, Biobío Province, Biobío Region, Chile, collected by R. Donoso-Barros, XII1969. MZUC-23192, adult female, Nuble National Reserve, Butamayín Pass, Nuble Province, Biobío Region, Chile, collected by V. Quintana, 26-XI-1993. MZUC-23291-92, 
23294, 23298, 23300, adult males, Picontreñe, East of Laja Lake, Biobío Province, Biobío Region, Chile, collected by P. Victoriano, 31-I-1987. MZUC-23295, juvenile in Picontreñe, East of Laja Lake, Biobío Province, Biobío Region, Chile, collected by P. Victoriano and J.C. Ortiz, 31I-1987. MZUC-23296-97, adult females, Picontreñe, East of Laja Lake, Biobío Province, Biobío Region, Chile, collected by P. Victoriano, I-1987. MZUC-23299, adult females, Picontreñe, East of Laja Lake, Biobío Province, Biobío Region, Chile, collected by E. Habit, 31-I-1987. MZUC23304, adult male, slope of Antuco Volcano, Laguna del Laja National Park, Biobío Province, Biobío Region, Chile, collected by P. Victoriano, 15-II-1987. MZUC-23305, adult female, Antuco Volcano, National Park Laguna del Laja, Biobío Province, Biobío Region, Chile, collected by P. Victoriano, 15-II-1987; MZUC-23306, adult female, Las Playas, Laguna del Laja National Park, Biobío Province, Biobío Region, Chile, collected by H. Ibarra, 17-II-1987. MZUC-23307, adult female, Piedra del Indio, East of Laja Lake, Biobío Province, Biobío Region, Chile, collected by E. Habit, 15-II-1987. MZUC-23309, adult male in Los Barros, at $1 \mathrm{~km}$ east of the slopes of Antuco Volcano, Biobío Province, Biobío Region, Chile, collected by P. Victoriano, 6-XII-1986. MZUC-23310, adult female, Las Playas, Laguna del Laja National Park, Biobío Province, Biobío Region, Chile, collected by P. Victoriano, 11-XI-1987. MZUC-23311-12, adult females, Las Playas, Laguna del Laja National Park, Biobío Province, Biobío Region, Chile, collected by P. Victoriano, 17-II-1987. MZUC-23313, adult male, Alto Biobío, Shore of Icalma Lake, Malleco Province, Araucanía Region, Chile, collected by J.C. Ortiz, 17-III1990. MZUC-23315, 23318, 23321, adult males, Lonquimay, Pino Hachado Pass, Malleco Province, Araucanía Region, Chile, collected by L. Peña, XII-1961..MZUC-23316, adult female, Lonquimay, Pino Hachado Pass, Malleco Province, Araucanía Region, Chile, collected by L. Peña, XII-1961. MZUC-23323, 23326, adult males, Petronquines, shore of Laja Lake, Biobío Province, Biobío Region, Chile, collected by R. Donoso-Barros, 5-II-1970. MIC-006, adult male, Llao Lleo River, Neuquén Province, Argentina, collected by M. Christie, 22-XI-1987. MIC-007, adult male, Caña Plantada, road to Río Malleo, Neuquén Province, Argentina, collected by I. Belke, 20-III-1983. MIC-011, juvenile, Caña Plantada, Lanín National Park, Neuquén Province, Argentina collected by P.H. Borraz, 14-II-1983 MIC-028, juvenile, en Huechulafquén National Park, Huiliches Department, Neuquén Province, Argentina, collected by D. Vega, 17II-1983. MIC-046, juvenile, near Rucachoroi Lake, Lanín National Park, Aluminé Department, Neuquén Province, Argentina, collected by I. Belke, 20-II-1983. MIC-075, juvenile, Chapelco range, Lácar Department, Neuquén Province, Argentina, collected by B. Feingold, 20-III1983. MIC-077, juvenile, Traful Sectional Pass, Los Lagos Department, Neuquén Province, Argentina, collected by M. Buttini, 19-I-1983. MIC-081, adult female, Huechulafquén National Park, Huiliches Department, Neuquén Province, Argentina, collected by D. Vega, 17-II-1983. MIC-082, 084 adult females, Cerro Trujillo, Aluminé Department, Neuquén Province, Argentina, collected by I. Belke, 26II-1983. MIC-083, 085, juveniles, Cerro Trujillo, Aluminé Department, Neuquén Province, Argentina, collected by I. Belke, 26-II-1983. MIC-089, adult female, Cerro Otto, Bariloche Department, Río Negro Province, Argentina, collected by D. Bettinelli, 16-IV-1984. MIC-762, adult female, Lago Caviahue Aerodrome, Norquín Department, Neuquén Province, Argentina collected by I. Christie,1-II1988. MIC-890, adult female, Río Agrio Bridge, Norquín Department, Neuquén Province, Argentina, collected by M. Christie, 1-II-1988. MIC-1080, adult female, Laguna Blanca, Zapala Department, Neuquén Province, Argentina, 17-III-1994. MIC-1110, adult male, Cerro Las Ardillas, Nahuel Huapi National Park, Río Negro/Neuquén Province, Argentina, collected by M. Christie, 2-II-1994. MIC-1144, adult female, in Cerro Las Ardillas, Nahuel Huapi National Park, Río Negro/Neuquén Province, Argentina, collected by M. Christie 21-XII-1994. MIC-1174, adult female, Portal La Atravesada, Neuquén Province, Argentina, collected by M. Christie 15-II-1995. MIC-1176, adult male, Portal La Atravesada, Neuquén Province, Argentina, collected by M. Christie, 15-II-1983. MIC-1185, adult female, in Zapala Station, Zapala Department, Neuquén Province, Argentina, collected by M. Christie 15-II-1995. MIC-1196, 1202, adult females, Los Lagos Department, Neuquén Province, Argentina, collected by M. Christie 9-III-1995. 